\title{
POEMS OF AN INTERNET TRAWLER
}

\author{
Zeny May Dy Recidoro \\ zmdrecidoro@gmail.com
}

\begin{abstract}
About the Author
Zeny May Dy Recidoro graduated with a degree in Art Studies from the University of the Philippines Diliman. She is a former member of the UP Writers Club. Her works have been published in journals such as qarrtsiluni, Cha: an Asian Literary Journal, and Hong Kong University's Yuan Yang, and in anthologies such as Eastern Heathens and Thursday Never Looking Back. Her interests include psychogeography and the uncanny.
\end{abstract}




\section{Veiled Sympathy: Old News}

I.

In a province tucked in its own time, years ago

there were reported sightings of a red cloud

hovering-by an old couple herding goats, some children on their way, baa-ing and bawling,

a man selling honey, all announcing ominously in the streets

(but the only stirring: banners of the perpetual re-elect, rising and falling with ease, carried by the wind they also dared seize):

weeks later a massacre occurred on the exact same spot

where the red cloud hovered.

A cow and a big white bird, stood by with speechless eyes

(and they saw it done several times in one night).

Some erudite woman remarked,

"Death's calling card." It caught on, a cold

coming down upon a bone-worn nation.

II.

The culprit stands behind bars,

leaning against the shabby, toothpaste--colored wall,

with a face that "hee hee hee hee-d" while

images of mangled bodies and a back-hoe

(imagine blood and dirt and the freshness of grass,

cries and laments that went by un-hee-hee-hee-heeded)

confounded eyes behold villain and victim,

transmitted by satellite "hee

hee hee hee" on T.V.

Oh but T.V. still says

he is only an "alleged culprit,"

and has recently been pardoned:

A big, black bird perched on an old,

old tree at the site goes

"haw, haw, haw, haw."

The culprit departs

under the cloak of the sensational carnivalesque,

an endless parade of petty dramedies,

there is no place here for lofty tragedies,

forgotten by most, the voices of those who remember become echoes 
drowned as they fall into the void of other stories, countless cries, faults called out, rumbling earth, trembling sky, deaths and abandoned lives lamented but never resolved.

III.

Red cloud, black bird,

The dead buried by a backhoe unites the island home, island prison in shadow-plays and tell-tales, the nation with conviction and indignation as light as air. In parts distant, unknown, the living others continuing to exist, the living content blanketed by peace, survivors by default, guiltless and free (by their own devices), they continue their own processions and extant ritualsveiled sympathy, they pray but wonder the feeling, as if everything happened in another country. Distance: indifference is suspect but inevitable. 


\section{Missing}

No evidence to prove he had run away.

Everything was in order in that small space,

every kind of creature comfort,

how could he ever want to leave?

Yet there are other things:

locks of hair, scratches on the walls and doorframe,

a nail on the banister had been bent

(what pain it must've caused).

His mother thought of various scenes

of his abduction (was it) but

with only one conclusion (at the end

of her string of understanding,

she wants to believe, and wants

someone to convince her otherwise):

he was out wandering, a novice wanderlust

intensely unprepared. A question hangs soundless, bell-

rope without bell. Being yearning to be fulfilled.

As soon as he disappeared, she roamed the city, reminded that in each turn was a reservoir of familiar senses the body knew too well.

How could the self-same memory be lost?

The possibility of never recovering

intensified by time and an unoccupied room.

Tools of surveillance yielded so little,

all-seeing yet still curiously oblivious

to the intentions of the disappeared. Only offering

a fragment, a snippet of a moment of departure.

For comfort she settles

uneasily spending her days

tying up, sewing, knitting, weaving

loose strings, but still ending up

with unfinished pieces: a shirt

missing an arm, a scarf

with loose threads like nerve ends, gloves

without fingers, each day

ending open, dead-

ended, closed. 


\section{About Cat or How a Cat Adopts Itself into}

\section{Your Home in Three Steps}

$\operatorname{Leg} R u b$

A cat roams the streets looking for its bone.

Even cats have their bones to pick:

chicken, fish, big cartoon bones

that look like the human humerus,

the lost howling bones of an abusive parent.

Imagine what the cat's life must be like,

it must be like a GIF: little spastic movements, repeat, repeat, repeat: they say: the only art that cannot be bought. Eccentric, peculiar-elegant, can get through the toughest days.

Give the cat a pat and it will be mortified

beyond relief: "Oh no, why do you like me so what? I don't care. Good-

bye (?)"

Soft, fat, round, and homeless, from behind a Q, as such: Qat, a Question too: how many lives does a questionable cat have? Falling from a high and dangerous place, a cat is saved by its promiscuity.

Purr and Big Eyes (Hurtful Games)

When you love a cat, a man-cat, here are the names that might be given to you: Voluptuous Temptress, Seductive Siren.

When he is angry, you are a: Dirty Whore Mouth, Cock Hungry Slut. 
A man-cat's moustache-whiskers curl up and quiver, will give you a touch to send your heart a titter, to warm cold nights, and cool warm days.

Affection is a mystery best felt rather than spoken, affection is an affliction served with a yearning, resentful embrace.

When a cat loves you, he will have then left a cold trail of lust and memory, for cats are masters in stealth games, and make the tenderest terrible lovers.

When you love and have been loved by a cat, it is better to do so at a distance, behind walls, behind the screen, in watchful silence, intimate solitude.

Claim Prime Space: Couch, Middle of Bed, Top of Pridyider

A cat roams above our heads, on the roofs of our beds, it makes a sound like skeletons dancing the dance of the unliving, then it sleeps on a pile of magazines dedicated to high lives $\mathrm{s}(\mathrm{h})$ itting on low-lifes, a cat is the high judge who sleeps with one eye open. How homeless the noble cat, it reminisces its days in ancient cities, once feared and worshipped, no place for affection (but perhaps, as the old ones have done, only showed it behind curtains, veils, and screens), in cities now near rubble, full of bones where empires have pissed-passed, are passing-pissing. 